\title{
Performance of Booroola Merino and Finnsheep crossbred lambs and ewes
}

\author{
L. D. YOUNG and G. E. DICKERSON
}

Roman L. Hruska U.S. Meat Animal Research Center, ARS, USDA, Clay Center, NE 68933, U.S.A. and University of Nebraska, Lincoln, NE 68583, U.S.A.

\begin{abstract}
Booroola Merino $(\mathrm{B}, \mathrm{n}=18)$ and Finnsheep $(\mathrm{F}, \mathrm{n}=31)$ rams were mated to $\mathrm{F}$ ewes and $\mathrm{C} 3$ ewes (1/2 Columbia, 1/4 Suffolk, 1/4 Hampshire). Progeny of these matings were evaluated for performance traits including ewe reproduction through 3 years of age. Averaged over dam breeds, there was no significant difference between B and F sires for conception rate (CR), litter size (LS) at birth or weaning or for lamb mortality to weaning. The difference among sire breeds was not large or significant for birth weight but $\mathrm{F}$ sired lambs were significantly heavier than B sired lambs at 63 and 147 days of age. Relative to F sired lambs, B sired lambs had a higher dressing percentage and less fat at the 12 th rib but equal estimated percentage kidney fat. A significantly smaller percentage of B-C3 than F, F-C3 or B-F ewe lambs reached puberty by the end of their first breeding season. Ovulation rate at first mating was higher but embryo survival rate tended to be lower for B sired ewes than for F sired ewes. At 2 years of age, B sired ewes produced about $1 \mathrm{~kg}$ more wool than $\mathrm{F}$ sired ewes. With the exception of the very poor CR of B-C3 ewes at first parity, the differences between the four ewe genotypes were not large or significant for CR at first, second and third parity. The difference between $\mathrm{B}$ and $\mathrm{F}$ sired ewes in LS at birth was not significant at first parity but B sired ewes were more prolific at second and third parities. However, differences in lamb mortality reduced, and in some cases removed, the differences in LS by weaning time. Relative use of these breeds in commercial U.S. production schemes is discussed.
\end{abstract}

Index words: Finnsheep, Booroola Merino, ovulation rate, conception rate, litter size, embryo survival, lamb weight, fleece weight, carcass

\section{Introduction}

A major component of sheep breeding research at MARC has focused on the use of Finnsheep $(\mathrm{F})$ in crossbreeding programs to increase reproductive rate. Research has shown that for every $1 \%$ increase in $\mathrm{F}$ breeding in the ewes, there is a $1 \%$ increase in lambs born per ewe (1). Consequently, $\mathrm{F}$ have been used widely to produce crossbred ewes for intensive lamb production in the U.S. The Booroola Merino (B) is an alternative source of genes to increase prolificacy (2). The B is unique because it has a single major gene that increases 
ovulation rate (OR) and consequently litter size (LS) and it is the only known highly prolific breed with an unpigmented, Merino-quality fleece. The different genetic mechanisms controlling prolificacy in the $\mathrm{F}$ and $\mathrm{B}$ offer alternative opportunities for development of breeding and production programs to increase the level of reproduction in commercial sheep flocks. However, data are lacking on direct comparison of these breeds for performance traits measured throughout the life cycle which is necessary to make informed decisions on the alternative use of these breeds in crossbreeding programs.

With the cooperation of the New Zealand Ministry of Agriculture and Fisheries, 5 adult $B$ rams and 21 Coopworth ewes impregnated with $\mathrm{B}$ embryos were imported to MARC in the fall of 1983. A project involving the $\mathrm{F}$ and B was initiated in December of 1983. This paper will report data on lambs and ewes resulting from matings of $\mathrm{B}$ and $\mathrm{F}$ rams to $\mathrm{F}$ and crossbred ewes.

\section{Materials and methods}

$\mathrm{B}$ and $\mathrm{F}$ rams were mated to ewes and crossbred ewes (1/2 Columbia, 1/4 Suffolk, 1/4 Hampshire, hereafter referred to as C3) for 35 days beginning in mid-December of 1983, 1984, 1985 and 1986. Matings were made in outside dirtlots with about 20 ewes per ram. A total of $31 \mathrm{~F}$ and $18 \mathrm{~B}$ rams were used for breeding. Several B rams were used in more than one year because of the limited number available. A few $\mathrm{F}$ rams were also repeated. Ewes were managed as one group. Lambs were born and raised in a facility with an elevated, woven-wire floor. Lambs were weighed at birth and at an average of 63 (weaning) and 147 days of age. Rams not needed as replacements were slaughtered in groups of approximately 60 after reaching $45.5 \mathrm{~kg}$ live weight, and carcass data were recorded. All healthy ewe lambs were moved to outside dirtlots and monitored for age at first estrus by exposure to vasectomized rams beginning at 21 weeks of age. At approximately 7 months of age, all sound, healthy ewe lambs were exposed to fertile rams for 35 days. Breeding marks were recorded three times a week prior to breeding and daily during breeding. OR was evaluated by laparoscopic examination 7 to 10 days after the first mating of each ewe lamb to a fertile ram. Embryo survival $(\mathrm{ES}=$ number of lambs born per egg ovulated) was.measured in firstcross and purebred $\mathrm{F}$ ewes born in 1984, 1985 and 1986 that were bred to lamb at one year of age. The data on ES included all ewes that had a recorded OR whether they lambed or not. In 12 of the 360 observations, the recorded OR was less than the number of lambs born and OR was set equal to number born. Fleece weight was recorded at shearing one month prior to lambing at 2 years of age for ewes born in 1984, 1985, and 1986.

First-cross and contemporary purebred $\mathrm{F}$ ewes were evaluated for reproduction through three years of age. The first-cross B-C3 and F-C3 ewes were mated to $\mathrm{C} 3$ rams to compare the ewe genotypes for reproduction. $\mathrm{F}$ ewes were mated to $\mathrm{B}$ and $\mathrm{F}$ rams. The first-cross $\mathrm{B}-\mathrm{F}$ ewes were mated to $\mathrm{B}, \mathrm{F}$ and $\mathrm{B}-\mathrm{F}$ rams. The main purpose of these matings was to produce ewes varying in $\mathrm{F}$ breeding and frequency of the Booroola fecundity gene to determine the effect of the Booroola fecundity gene in a more prolific genetic background. Individual and maternal heterosis $(\mathrm{H})$ effects are included in performance of reciprocal backcrosses and $F_{2}$ matings but not in the performance of purebred F. Despite this complication, the comparison of the average performance of $\mathrm{F}$ ewes relative to the average performance of B-F ewes is included because it is of biological interest.

Comparisons between B-C3 and F-C3 lambs estimates one-half the additive genetic difference, all paternal effect differences and differences in specific individual H. Comparisons among ewes of these genotypes estimates one-quarter of the additive genetic difference and one-half the maternal genetic difference. Comparison between $\mathrm{F}$ and B-F lambs esti- 
mates one-half the additive genetic difference, all paternal effect differences and all individual $\mathrm{H}$. Comparisons of the average performance of the $\mathrm{F}$ ewes to the average performance of the B-F ewes estimates one-quarter of the additive genetic difference, one-half the maternal genetic difference and all of the maternal $\mathrm{H}$.

At the time of the importation, all mature $\mathrm{B}$ rams and the embryos carried by Coopworth ewes were thought to be homozygous for the Booroola fecundity gene based on pedigree. Later, information of progeny suggested that the sire of some of the imported rams may be heterozygous. Reproductive data on the progeny of the imported rams suggested that only one ram was not homozygous. Thus, his daughters have been removed from the reproductive data. His progeny are left in the data for the other traits since there is no suggestion in the literature that the Booroola fecundity gene affects any other traits (2).

Data were analyzed by least-squares procedures utilizing various fixed models. Reproductive data of $\mathrm{F}$ and $\mathrm{C} 3$ ewes mated to $B$ and $F$ rams were analyzed with a model that included the effects of year, sire breed, dam breed, age of ewe, sire breed $\times$ dam breed, and of ewe $\times$ dam breed. Age of ewe was considered as a fixed effect of ewes lambing at 1,2, 3, 4, and 5 or more years of age. The linear effect of age and its interaction with sire breed, dam breed and sire breed $\times$ dam breed were added to the basic model for analysis of lamb weights at birth, weaning (63 days of age) and 147 days of age. Slaughter weight and its interaction with sire breed, dam breed and sire breed $\times$ dam breed were added to the basic model for analysis of carcass weight. Carcass weight and its interaction with sire breed, dam breed and sire breed $\times$ dam breed were added to the basic model for the analysis of 12th rib fat thickness and estimated percentage kidney fat. Puberty traits, OR at first breeding and fleece weight at 2 years of age were analyzed with the basic model.

The model to analyze ES included the effects of year and mating type. There were sev- en mating types: $\mathrm{C} 3$ rams mated to $\mathrm{B}-\mathrm{C} 3$ and $\mathrm{F}-\mathrm{C} 3$ ewes, $\mathrm{F}$ rams mated to $\mathrm{F}$ and $\mathrm{B}-\mathrm{F}$ ewes, $\mathrm{B}$ rams mated to $\mathrm{F}$ and $\mathrm{B}-\mathrm{F}$ ewes and $\mathrm{B}-\mathrm{F}$ rams mated to B-F ewes. Conception rate and LS of first-cross and purebred $\mathrm{F}$ ewes was analyzed with a model that included the effects of year, parity $(1,2,3)$, mating type and the interaction of parity and mating type. Linear combinations of the least-squares means were made to estimate the average performance of F ewes (mated to B and $\mathrm{F}$ rams) and B-F ewes (mated to B, F and B-F rams). In general, the effect of ram breed within ewe breed was not large or significant for the traits evaluated. Thus, the performance of $\mathrm{F}$ and B-F ewes averaged across breed of sire appeared to be the best overall estimate of the performance of these ewe genotypes.

\section{Results}

Least-squares means for conception rate, litter size at birth and weaning and lamb mortality to weaning for $\mathrm{F}$ and $\mathrm{C} 3$ ewes mated to $\mathrm{F}$ and $\mathrm{B}$ rams are presented in table 1. Levels of statistical significance for the effects of sire breed, dam breed and their interaction are also presented in table 1. There was a significant interaction between sire breed and dam breed for conception rate (CR). B rams had a higher conception rate than $\mathrm{F}$ rams when mated to $\mathrm{F}$ ewes but a slightly lower CR when mated to $\mathrm{C} 3$ ewes. Breed of ram was not significant when averaged over breed of ewe. $F$ ewes had a higher CR than C3 ewes for both breeds of ram but this difference was larger for B rams $(11.0 \%)$ than for $\mathrm{F}$ rams $(1.4 \%)$. The main effect of sire breed and the interaction of sire breed and dam breed were not significant for LS at birth, LS at weaning or lamb mortality from birth to weaning. F ewes had larger litters at birth and weaning than $\mathrm{C} 3$ ewes. Lamb mortality was also higher in litters from $\mathrm{F}$ dams than in litters from C3 dams likely reflecting the expected increase in mortality with an increase in LS at birth.

Least-squares means for individual lamb weights at birth, 63 days of age (weaning) and 
Table 1. Least-squares means and significance levels for reproductive traits of $\mathrm{C} 3$ and $\mathrm{F}$ ewes mated to B and $\mathrm{F}$ rams.

\begin{tabular}{|c|c|c|c|c|c|c|c|}
\hline \multirow[b]{2}{*}{$\begin{array}{l}\text { Sire } \\
\text { breed }\end{array}$} & \multirow[b]{2}{*}{$\begin{array}{l}\text { Dam } \\
\text { breed }\end{array}$} & \multicolumn{2}{|c|}{$\begin{array}{l}\text { Conception } \\
\text { rate, } \%\end{array}$} & \multirow[b]{2}{*}{$\begin{array}{l}\text { No. } \\
\text { litters }\end{array}$} & \multirow[b]{2}{*}{$\begin{array}{l}\text { No. } \\
\text { born }\end{array}$} & \multirow[b]{2}{*}{$\begin{array}{c}\text { No. } \\
\text { weaned }\end{array}$} & \multirow[b]{2}{*}{$\begin{array}{c}\text { Percent } \\
\text { mortality }\end{array}$} \\
\hline & & No. & Mean & & & & \\
\hline Finn & Finn & 294 & 77.0 & 226 & 2.60 & 1.83 & 26.6 \\
\hline Boor & Finn & 360 & 83.8 & 308 & 2.52 & 1.83 & 24.8 \\
\hline Finn & $\mathrm{C} 3$ & 315 & 75.6 & 240 & 1.61 & 1.51 & 5.8 \\
\hline Boor & $\mathrm{C} 3$ & 340 & 72.8 & 251 & 1.57 & 1.39 & 10.9 \\
\hline \multicolumn{2}{|c|}{ Range of S.E." } & & $2.4-2.9$ & & $.04-.05$ & $.05-.06$ & $1.9-2.3$ \\
\hline \multicolumn{8}{|c|}{ Model effect ${ }^{b}$} \\
\hline \multicolumn{2}{|c|}{ Sire breed } & \multicolumn{2}{|r|}{ n.s. } & & n.s. & n.s. & n.s. \\
\hline \multicolumn{2}{|c|}{ Dam breed } & \multicolumn{2}{|r|}{.03} & & .0001 & .0001 & .0001 \\
\hline \multicolumn{2}{|c|}{ Sire breed $\times$ Dam breed } & & .04 & & n.s. & n.s. & .06 \\
\hline
\end{tabular}

a S.E. is standard error.

b Level of significance for the model effect. n.s. is not significant, $P>.05$.

Table 2. Least-squares means and significance levels for weight at birth, 63 days (weaning) and 147 days of age of lambs produced from mating $\mathrm{C} 3$ and $\mathrm{F}$ ewes to $\mathrm{B}$ and $\mathrm{F}$ rams.

\begin{tabular}{|c|c|c|c|c|c|c|c|}
\hline \multirow{2}{*}{$\begin{array}{l}\text { Sire } \\
\text { breed }\end{array}$} & \multirow{2}{*}{$\begin{array}{l}\text { Dam } \\
\text { breed }\end{array}$} & \multicolumn{2}{|c|}{$\begin{array}{c}\text { Birth } \\
\text { wt, kg }\end{array}$} & \multicolumn{2}{|c|}{$\begin{array}{l}\text { 63-day } \\
\text { wt, kg }\end{array}$} & \multicolumn{2}{|c|}{$\begin{array}{c}147-\text { day } \\
\text { wt, kg }\end{array}$} \\
\hline & & No. & Mean & No. & Mean & No. & Mean \\
\hline Finn & Finn & 574 & 2.87 & 417 & 16.9 & 385 & 33.3 \\
\hline Boor & Finn & 743 & 2.89 & 559 & 15.2 & 526 & 31.6 \\
\hline Finn & $\mathrm{C} 3$ & 399 & 5.17 & 370 & 23.5 & 345 & 43.4 \\
\hline Boor & $\mathrm{C} 3$ & 412 & 5.21 & 343 & 20.5 & 342 & 39.1 \\
\hline \multicolumn{2}{|c|}{ Range of S.E.a } & & .04 & & $.2-.3$ & & .4 \\
\hline \multicolumn{8}{|c|}{ Model effect ${ }^{b}$} \\
\hline \multicolumn{2}{|c|}{ Sire breed } & & n.s. & & .0001 & & .0001 \\
\hline \multicolumn{2}{|c|}{ Dam breed } & & .0001 & & .0001 & & .0001 \\
\hline \multicolumn{2}{|c|}{ Sire breed $\times$ Dam breed } & & n.s. & & .008 & & .0004 \\
\hline
\end{tabular}

a S.E. is standard error.

b Level of significance for the model effect. n.s. is not significant, $P>.05$.

147 days of age are presented in table 2. Levels of statistical significance for the effects of sire breed, dam breed and their interaction are also presented in table 2 . The main effect of sire breed and the interaction of sire breed and dam breed were not significant for birth weight. Lambs from $\mathrm{F}$ dams were significantly lighter at birth than lambs from C3 dams. However, at weaning and 147 days of age the interaction of sire breed and dam breed was significant. Lambs sired by $\mathrm{F}$ rams were significantly heavier at weaning and at 147 days of age than lambs sired by $B$ rams regardless of breed of dam. However, the difference be- tween ram breeds was larger in progeny from C3 dams (4.3 kg at 147 days of age) than those from $\mathrm{F}$ dams ( $1.7 \mathrm{~kg}$ at 147 days of age).

Least-squares means for carcass traits are shown in table 3 . Levels of statistical significance for the effects of sire breed, dam breed and their interaction are also presented in table 3. The interaction of sire breed and dam breed was not significant for carcass weight at a constant slaughter weight of 48.3 $\mathrm{kg}$, or for 12th rib fat thickness and estimated percentage kidney fat at a constant carcass weight of $25.4 \mathrm{~kg}$. F-sired rams had a larger carcass weight and less 12 th rib fat thickness 
Table 3. Least-squares means and significance levels for carcass traits of ram lambs and fleece weight of 2-year-old ewes produced from mating $\mathrm{C} 3$ and $\mathrm{F}$ ewes to $\mathrm{B}$ and $\mathrm{F}$ rams.

\begin{tabular}{|c|c|c|c|c|c|c|c|}
\hline \multirow{3}{*}{$\begin{array}{l}\text { Sire } \\
\text { breed }\end{array}$} & \multirow{3}{*}{$\begin{array}{l}\text { Dam } \\
\text { breed }\end{array}$} & \multicolumn{4}{|c|}{ Carcass traits } & \multirow{2}{*}{\multicolumn{2}{|c|}{$\begin{array}{l}\text { Fleece } \\
w t, k g\end{array}$}} \\
\hline & & \multirow[b]{2}{*}{ No. } & \multirow{2}{*}{$\begin{array}{l}\text { Carcass } \\
\text { wt, kg }{ }^{\mathrm{a}}\end{array}$} & \multirow{2}{*}{$\begin{array}{l}\text { 12th rib fat } \\
\text { depth, } \mathrm{cm}^{\mathrm{b}}\end{array}$} & \multirow{2}{*}{$\begin{array}{l}\text { Est. kidney } \\
\text { fat, } \% \text { b }\end{array}$} & & \\
\hline & & & & & & No. & Mean \\
\hline Finn & Finn & 102 & 25.6 & .238 & 2.53 & 106 & 2.1 \\
\hline Boor & Finn & 182 & 25.0 & .328 & 2.57 & 138 & 3.2 \\
\hline Finn & $\mathrm{C} 3$ & 169 & 26.1 & .310 & 2.14 & 113 & 3.2 \\
\hline Boor & $\mathrm{C} 3$ & 163 & 25.2 & .375 & 2.18 & 104 & 3.9 \\
\hline \multicolumn{2}{|c|}{ Range of S.E.c } & & .1 & $.009-.012$ & $.05-.07$ & & .1 \\
\hline \multicolumn{8}{|c|}{ Model effect ${ }^{\mathrm{d}}$} \\
\hline \multicolumn{2}{|c|}{ Sire breed } & & .0001 & .0001 & n.s. & & .0001 \\
\hline \multicolumn{2}{|c|}{ Dam breed } & & .034 & .0001 & .0001 & & .0001 \\
\hline \multicolumn{2}{|c|}{ Sire breed $\times$ Dam breed } & & n.s. & n.s. & n.s. & & .014 \\
\hline
\end{tabular}

a Adjusted to mean live weight of $48.3 \mathrm{~kg}$.

b Adjusted to mean carcass weight of $25.4 \mathrm{~kg}$.

c S.E. is standard error.

¿ Level of significance for the model effect. n.s. is not significant, P>.05.

than did B-sired rams, however the difference in estimated percentage kidney fat was not significant. Ram lambs from $\mathrm{F}$ ewes had smaller carcasses, less 12th rib fat thickness and a higher estimated percentage kidney fat than ram lambs from $\mathrm{C} 3$ ewes.

Least-squares breed group means for fleece weight of 2-year-old ewes are also shown in table 3. The interaction of breed of sire and breed of dam was significant for fleece weight. Ewes sired by B rams produced heavier fleeces than did ewes sired by $F$ rams regardless of breed of dam. However, relative to fleeces from F-sired ewes, fleeces from B-sired ewes were $1.1 \mathrm{~kg}$ heavier from ewes out of $\mathrm{F}$ dams and only $.7 \mathrm{~kg}$ heavier from ewes out of $\mathrm{C} 3$ dams.

Least-squares means for puberty traits and OR of ewe lambs are presented in table 4. Levels of statistical significance for the effects of sire breed, dam breed and their interaction are also presented in table 4 . There was a significant sire breed $\times$ dam breed interaction for percentage of ewe lambs that reached puberty by the end of the first breeding season. Approximately $94 \%$ of the ewes sired by F rams reached puberty regardless of the breed of dam. However, only $60 \%$ of the B-sired ewe lambs out of C3 dams reached puberty while
$93 \%$ of those out of F dams reached puberty. Only the effect of sire breed was significant for age at puberty. Of the ewe lambs that showed puberty, F-sired ewe lambs were almost 9 days younger at puberty than B-sired ewe lambs. OR of ewe lambs that mated during their first breeding season was higher for lambs from B sires than those from $F$ sires and higher for lambs from $\mathrm{F}$ dams than those from C3 dams. One copy of the Booroola fertility gene increased OR of ewe lambs by .35 more eggs than did a sample half of the Finnsheep prolificacy genes.

Despite fairly large differences, the effect of mating type on ES was not significant. The least-squares means, standard errors and number of observations were: $81.1 \pm 4.2,99$; $73.8 \pm 3.9,120 ; 84.5 \pm 4.4,94$; and $66.7 \pm 6.2$, 47 for F, B-F, F-C3 and B-C3 ewes, respectively. Although the differences were not statistically significant, the ewes sired by B rams had lower ES rates than did ewes sired by $\mathrm{F}$ rams.

The distribution of number of F, B-F, F$\mathrm{C} 3$ and B-C3 by parity are shown in table 5 . There are more data on first parity than second parity and even less on third parity because ewes born in 1984, 1985 and 1986 contribute to first parity; ewes born in 1984 and 
Table 4. Least-squares means and significance levels for puberty traits and ovulation rate of ewe lambs produced from mating $\mathrm{C} 3$ and $\mathrm{F}$ ewes to $\mathrm{B}$ and $\mathrm{F}$ rams.

\begin{tabular}{|c|c|c|c|c|c|c|c|}
\hline \multirow{2}{*}{$\begin{array}{l}\text { Sire } \\
\text { breed }\end{array}$} & \multirow{2}{*}{$\begin{array}{l}\text { Dam } \\
\text { breed }\end{array}$} & \multicolumn{2}{|c|}{$\%$ Pubertal } & \multicolumn{2}{|c|}{ Puberty age, d } & \multicolumn{2}{|c|}{ Ovulation rate } \\
\hline & & No. & Mean & No. & Mean & No. & Mean \\
\hline Finn & Finn & 191 & 94.6 & 181 & 183.1 & 135 & 2.12 \\
\hline Boor & Finn & 229 & 93.3 & 210 & 189.4 & 183 & 2.56 \\
\hline Finn & $\mathrm{C} 3$ & 177 & 94.2 & 163 & 179.6 & 148 & 1.62 \\
\hline Boor & $\mathrm{C} 3$ & 158 & 60.3 & 94 & 190.6 & 69 & 1.89 \\
\hline \multicolumn{2}{|c|}{ Range of S.E.a } & & $2.1-2.5$ & & $1.4-2.1$ & & $.05-.08$ \\
\hline \multicolumn{8}{|c|}{ Model effects } \\
\hline \multicolumn{2}{|c|}{ Sire breed } & & .0001 & & .0001 & & .0001 \\
\hline \multicolumn{2}{|c|}{ Dam breed } & & .0001 & & n.s. & & .0001 \\
\hline \multicolumn{2}{|c|}{ Sire breed $\times$ Dam breed } & & .0001 & & n.s. & & n.s. \\
\hline
\end{tabular}

a S.E. is standard error.

b Level of significance for the model effect. n.s. is not significant, $\mathrm{P}>.05$.

Table 5. Least-squares means and standard errors for conception rate by breed of ewe and parity.

\begin{tabular}{|c|c|c|c|c|c|c|}
\hline \multirow[b]{2}{*}{ Ewe breed } & \multicolumn{3}{|c|}{$\begin{array}{l}\text { No. obs. } \\
\text { by parity }\end{array}$} & \multicolumn{3}{|c|}{ Mean conception rate by parity } \\
\hline & 1 & 2 & 3 & 1 & 2 & 3 \\
\hline Finnsheepa & 153 & 87 & 44 & $78.2 \pm 3.0$ & $92.9 \pm 4.2$ & $99.1 \pm 5.9$ \\
\hline Booroola-Finnsheep ${ }^{b}$ & 151 & 87 & 24 & $75.6 \pm 3.0$ & $97.0 \pm 4.1$ & $103.8 \pm 7.8$ \\
\hline Finnsheep-C3 & 114 & 64 & 9 & $78.0 \pm 3.5$ & $91.6 \pm 4.8$ & $81.5 \pm 12.4$ \\
\hline Boorola-C3 & 117 & 67 & 23 & $39.4 \pm 3.4$ & $95.7 \pm 4.6$ & $95.1 \pm 7.9$ \\
\hline
\end{tabular}

average performance when mated to Finnsheep and Booroola rams.

b Average performance when mated to Finnsheep, Booroola and Booroola-Finnsheep rams.

1985 contribute to second parity and only ewes born in 1984 contribute to third parity. Analysis of conception rate of ewes lambing at 1 , 2 and 3 years of age showed a significant interaction of mating type and parity. The leastsquares means for CR by breed of ewe and parity are shown in table 5 . The cause of the significant mating type by parity interaction is the exceptionally low CR of B-C3 ewe lambs bred to lamb at one year of age which is a reflection of the low percentage reaching puberty in this genotype. The differences between mating types in subsequent parities were not significantly different. CR at third parity for $\mathrm{F}$ ewes was relatively low (based on only 9 ewes) but not significantly lower than for the other breed groups.

The interaction of mating type and parity was significant for number of lambs born and number of lambs weaned but not for mortality. The least-squares means for number born by breed of ewe and parity are shown in table 6. The main cause of this significant interaction is the relatively small increase in LS at birth with an increase in parity expressed in F-C3 ewes relative to the other genotypes. The increase from 1st to 2nd parity is also larger in $\mathrm{B}-\mathrm{F}$ and $\mathrm{B}-\mathrm{C} 3$ ewes than in F and F-C3 ewes. The least-squares means for number weaned are presented in table 7 . The main causes of this significant interaction are a larger increase from first to second parity in B-C3 ewes than in F-C3 ewes and a larger increase from second to third parity in B-F ewes than for any of the other genotypes. It should be remembered that there is relatively little data on third parity females and it represents ewes from only one birth year. Least-squares means and 
Table 6. Least-squares means and standard errors for number of lambs born by breed of ewe and parity.

\begin{tabular}{|c|c|c|c|c|c|c|}
\hline \multirow[b]{2}{*}{ Ewe breed } & \multicolumn{3}{|c|}{$\begin{array}{l}\text { No. obs. } \\
\text { by parity }\end{array}$} & \multicolumn{3}{|c|}{$\begin{array}{l}\text { Mean litter size } \\
\text { at birth by parity }\end{array}$} \\
\hline & 1 & 2 & 3 & 1 & 2 & 3 \\
\hline Finnsheepa & 118 & 78 & 41 & $1.95 \pm .07$ & $2.55 \pm .09$ & $3.03 \pm .13$ \\
\hline Booroola-Finnsheep $^{b}$ & 108 & 73 & 21 & $1.96 \pm .07$ & $2.81 \pm .09$ & $3.44 \pm .17$ \\
\hline Finnsheep-C3 & 90 & 58 & 7 & $1.52 \pm .08$ & $1.86 \pm .10$ & $1.95 \pm .28$ \\
\hline Booroola-C3 & 42 & 57 & 17 & $1.39 \pm .12$ & $2.20 \pm .10$ & $2.66 \pm .28$ \\
\hline
\end{tabular}

average performance when mated to $\mathrm{F}$ and $\mathrm{B}$ rams.

b Average performance when mated to F, B and B-F rams.

Table 7. Least-squares means and standard errors for number of lambs weaned by breed of ewe and parity.

\begin{tabular}{lccr}
\hline & \multicolumn{3}{c}{ Mean litter size at weaning by parity } \\
\cline { 2 - 4 } Ewe breed & 1 & 2 & 3 \\
\hline Finnsheep $^{\mathrm{a}}$ & $1.43 \pm .08$ & $2.09 \pm .10$ & $2.47 \pm .13$ \\
Booroola-Finnsheep $^{\mathrm{b}}$ & $1.38 \pm .08$ & $2.08 \pm .10$ & $2.81 \pm .18$ \\
Finnsheep-C3 & $1.18 \pm .09$ & $1.73 \pm .11$ & $2.00 \pm .30$ \\
Booroola-C3 & $.93 \pm .12$ & $1.74 \pm .11$ & $2.00 \pm .20$ \\
\hline
\end{tabular}

average performance when mated to $\mathrm{F}$ and $\mathrm{B}$ rams.

b Average performance when mated to F, B and B-F rams.

standard errors for mortality were $25.0 \pm$ $3.6 \%, 9.1 \pm 4.6 \%, 20.9 \pm 3.1 \%$ and $19.9 \pm$ $2.5 \%$ for B-C3, F-C3, B-F and F ewes, respectively. Clearly, F-C3 ewes had less mortality which likely results from their lower overall LS at birth.

\section{Discussion}

The quantitative and qualitative inheritance of prolificacy in these breeds offer different approaches to increase prolificacy in purebred and crossbred populations. First-cross ewes could be produced from both $\mathrm{F}$ and $\mathrm{B}$ if the first cross ewe has satisfactory performance for other economically important traits besides reproduction.

F could be used to optimize the genetic level for reproduction in a composite or secondary crossbred population. The appropriate level of genes could be introduced into the crossbred or composite population to achieve optimal prolificacy, provided the effects of undesired genes from the $\mathrm{F}$ are negligible. This would not work well with the B since matings among non-homozygous individuals would result in at least two genotypes with different levels of prolificacy and these genotypes can only be distinguished by measuring OR or LS. Also, if the level of prolificacy resulting from one or two copies of the Booroola fecundity gene is not optimum for the production situation, there are no other levels of increased reproduction available with the major gene.

After several generations of backcrossing and intense selection for OR or LS, it should be possible to introduce the Booroola fecundity gene into any sheep population, increase its frequency to a very high level and reduce the frequency of other genes from the B to very low levels. This approach would be most appropriate if the high level of prolificacy provided by the homozygous genotype is optimum. This may also be desirable if the background genes of the B did not produce satisfactory performance in first-cross progeny.

This experiment was designed to compare two prolific breeds with each other rather than with a less prolific breed. This was done because a producer would consider using the $\mathrm{F}$ 
or B only if he wanted to increase reproduction. Thus, he would need information to decide which of these breeds to use not whether he should use these breeds or a less prolific breed. Based on the results presented here, the $\mathrm{B}$ seems less desirable than the $\mathrm{F}$ for increasing reproduction. The $\mathrm{B}$ grows slower than the F which is already criticized for its slow growth. More importantly the B is slow to reach puberty and only approximately $40 \%$ of crossbred ewes lambed at one year of age. This is a major economical disadvantage which is not easily offset by the increased wool production at current U.S. wool prices. An unexpected concern is that ewes that are heterozygous for the Booroola fecundity gene may be too prolific at second or later parities. Many producers feel that $1 / 2 \mathrm{~F}$ ewes are too prolific but the B-C3 ewes had larger litters at birth than F-C3 ewes. However, since mortality was nearly 3 times as high in litters from B-C3 ewes as that in F-C3 ewes, they each had about the same number of lambs at weaning.

If the Booroola fecundity gene is to make a significant contribution to the commercial sheep production in the U.S., it may be necessary to backcross the gene into another breed such as the Dorset or Rambouillet. The Dorset background genes may provide for a higher level of milk production and thus lower postnatal mortality in litters from crossbred ewes produced from B-Dorsets. Transferring the gene to the Rambouillet would provide a wool breed with high prolificacy that is better in growth than the B. B-Dorsets and B-Rambouillet, that are homozygous for the Booroola fecundity gene, could then be used to produce first-cross ewes that are more desirable than those produced by B. However, transfer of the gene into these breeds may be hampered by the higher level of reproduction in these breeds relative to the Merino so that heterozygous carriers of the Booroola fecundity gene may not be clearly identified.

\section{References}

1. Dickerson, G.E. 1977. Crossbreeding evaluation of Finnsheep and some U.S. breeds for market lamb production. North Centr Region. Publ. NO. 246.

2. PiPER, L.R. and Bindon, B.M. 1982. In: The

Booroola Merino, Proc. a workshop held at Armidale, NSW, 24-25 August, 1980, ed. L.R. PIPER, B.M. Bindon and R.D. Nethery, pp. 9-20. Melbourne: CSIRO Division of Animal Production. 